\title{
El nombre propio como modulador de vínculos sexo-afectivos y genealógicos en las novelas de Armonía Somers: una poética de la suplementariedad nominal
}

\author{
The Proper Name as a Modulator of Sexual, Affective \\ and Genealogical Ties in the Novels of Armonía \\ Somers: a Poetics of Nominal Supplementarity
}

\begin{abstract}
Resumen
Este artículo tiene como objetivo explorar la potencia del nombre propio como modulador identitario contingente en la novelística de la autora uruguaya Armonía Somers y, en específico, de la suplementariedad nominal (el acto de retorcer, sobreimprimir, desplazar o sustituir -a veces de forma momentánea- el nombre "original" o "legal" de los personajes por otro(s), como forma de deriva o fuga nominal). Dicha operación se propone como productora de transformaciones subjetivas de los personajes, tal como se verifica en ciertas zonas del discurso literario latinoamericano del siglo XX. Dentro de éstas se inscriben tres novelas de Somers: La mujer desnuda (1950), Sólo los elefantes encuentran mandrágora (1986) y Viaje al corazón del día: elegía por un secreto amor (1986), las cuales participan de dicha poética nominal. En dichos textos, y a partir de los desplazamientos nominales, se verifica la reconfiguración e incluso una inauguración de vínculos inéditos entre los personajes. De modo que el uso de este recurso temático, estructural y subjetivo excede el mero cambio de nomenclatura y se revela como un polo de producción subjetiva e intersubjetiva.
\end{abstract}


CATEDRAL TOMADA: Revista de crítica literaria latinoamericana / Journal of Latin American Literary Criticism

El nombre propio como modulador de vínculos sexo-afectivos y genealógicos en las novelas de Armonía Somers: una poética de la suplementariedad nominal

\begin{abstract}
This article explores the potential of the proper name as a contingent identity modulator in the Uruguayan author Armonía Somers' novels, and, specifically, of nominal supplementarity (the act of twisting, overprinting, displacing or substituting sometimes momentarily the "original" or "legal" name of the characters for another(s), as a form of nominal drift). This operation is presented as a producer of subjective transformations of the characters, as verified in certain areas of Latin American literary discourse in the 20th century. Among these are three novels by Somers: The naked woman (1950), Sólo los elefantes encuentran mandrágora (1986) and Viaje al corazón del día: elegía por un secreto amor (1986), which participate in this nominal poetics. In these texts, the nominal displacements cause the reconfiguration and even an inauguration of new forms of relationship between the characters. So the use of this thematic, structural, and subjective resource exceeds the mere change of nomenclature and reveals itself as a pole of subjective and intersubjective production.
\end{abstract}

Keywords

Uruguayan Literature, Armonía Somers, Literary subjectivities, Proper Names, Identity.

Quizás el cambio de identidad que eso entraña tuviera raíces existenciales más profundas de lo que parecían. Hay épocas en que vaciamos el ropero para arrojar malos recuerdos por la ventana junto con los vestidos que, si bien se los mira, son una segunda piel. Y quién sabe si aquel nombre nuevo con reminiscencias del verano en dos idiomas, no sería para mí como la piel brillante de la víbora que ha dejado la otra pasando entre dos piedras casi juntas.

Armonía Somers, (1966).

\title{
Introducción
}

Si un nombre nuevo puede ser, en palabras de Somers, una piel brillante de víbora que deja la anterior entre dos piedras casi juntas, entonces lo que está en juego -podría decirse- es la búsqueda de un hueco, de la abertura mínima que separa una piedra de la otra; un nombre del otro; una forma de subjetividad, sensibilidad (y quizás de corporalidad) de otra en la que deviene. ¿Cómo mutarse a uno mismo? ¿Cómo hacer la transición de una forma subjetiva a otra nueva? De 
una de las posibles respuestas - desde el discurso literario latinoamericano- se ocupa este trabajo crítico. Si, según Guattari y Rolnik, una forma de contraponerse a la subjetividad dominante es, precisamente, producir "subjetividades delirantes" (45) afirmamos que la novelística de Armonía Somers ${ }^{1}$ fabrica personajes literarios plásticos, en transformación, y que parte de dicha plasticidad deriva de un uso muy singular de los nombres propios, tal como nos encargaremos de describir y analizar en este trabajo.

Es necesario señalar, en primera instancia, que el horizonte sociológico y subjetivo en el cual esta indagación se inscribe toma como referencia la intensificación de las reformulaciones de las categorías de identidad y subjetividad que se producen durante últimas décadas del siglo XX. En estas concepciones posmodernas, la identidad se concibe de forma descentrada y no-esencialista. Entre diversos autores emergen ideas que asocian la identidad a la performatividad (Butler 84), al carácter narrativo (Ricoeur 324), procesual (Kristeva 250), de posicionalidad relacional (Hall 27), entre otros. Es decir, se introducen perspectivas que desafían la fijeza identitaria y privilegian sus cualidades mutables y plásticas.

La hipótesis de este trabajo es que en las novelas de la escritora uruguaya Armonía Somers se hace uso de una singular estrategia narrativa que elegimos denominar suplementariedad nominal y que consiste en el acto de retorcer, sobreimprimir, desplazar o sustituir -a veces de forma momentánea- el nombre "original" o "legal" de los personajes por otro(s), como forma de deriva o fuga nominal, y que ésta produce algún tipo de alteración o transformación subjetiva en ellos. Para esto, partimos de la idea de "suplemento" pensada por Jacques Derrida

\footnotetext{
1 Armonía Somers es el seudónimo de la escritora y pedagoga uruguaya Armonía Liropeya Etchepare Locino (1914-1994). Su obra narrativa, que irrumpe por primera vez en la escena montevideana en 1950 con la publicación de La mujer desnuda, indaga e introduce finos cuestionamientos sobre las temáticas de la religión y la moral; de la subjetividad; del género y de cuestiones político-sociales. Se posiciona, de este modo, como una autora disruptiva e imprescindible dentro del Uruguay a partir de mediados del siglo XX y su influencia se extiende, más tarde, hacia nuevos horizontes, con lo cual su obra adquiere proyección internacional.
} 
CATEDRAL TomadA: Revista de crítica literaria latinoamericana / Journal of Latin American Literary Criticism

El nombre propio como modulador de vínculos sexo-afectivos y genealógicos en las novelas de Armonía Somers: una poética de la suplementariedad nominal

como una forma sustitutiva y rotatoria que cuestiona (y desarticula) el carácter originario de toda presencia. ${ }^{2}$

La importancia de este mecanismo para el corpus reside en su carácter estructural, temático y subjetivo. Lejos de indicar un mero cambio de nomenclatura, dichos retorcimientos, sobreimpresiones, desplazamientos o sustituciones de los nombres de personajes introducen una disposición transversal en la economía de los textos consignados y formas de distribución narrativa de la subjetividad. Asimismo -y recurriendo a estudios de filosofía del lenguaje- sostenemos que la suplementariedad nominal tiene resonancias subjetivas efectivas sobre los personajes pero también sobre sus agenciamientos ${ }^{3}$ (Deleuze y Guattari 14) en el plano diegético: los modos de relación con los otros. Estos vínculos también se encuentran sujetos a modificaciones, reconfiguraciones e inauguraciones inéditos en La mujer desnuda, Sólo los elefantes encuentran mandrágora y Viaje al Corazón del día. Los agenciamientos allí trastocados por la suplementariedad nominal son de tipo sexo-afectivo y genealógico (de amplio espectro: familiar, simbólico, ideológico, etc.). ${ }^{4}$

\section{Aspectos teórico-metodológicos: los suplementos nominales y su aspecto lingüístico ${ }^{5}$}

Una arista insoslayable en relación con los nombres propios es, precisamente, su condición lingüística y filosófica, tal como fue descripta por la filosofía del lenguaje. Ésta puede iluminar algunas consecuencias subjetivas en

2 "Pero el suplemento suple. No se añade más que para reemplazar. Interviene o se insinúa en-lugar$d e$; si colma, es como se colma un vacío. Si representa y da una imagen, es por la falta anterior de una presencia. Suplente y vicario, el suplemento es un adjunto, una instancia subalterna que tienelugar" (Derrida 185).

${ }^{3}$ Entendidos como un "aumento de dimensiones en una multiplicidad que cambia necesariamente de naturaleza a medida que aumenta sus conexiones" (Deleuze y Guattari 14).

${ }^{4}$ En mi tesis de maestría denominada Subjetividades y nombres propios en las novelas de Armonía Somers: una poética de la suplementariedad nominal, de la cual deriva este artículo, abordé también el uso de los nombres en relación con las reconversiones de género.

${ }^{5}$ En relación con el aspecto lingüístico y filosófico, habría que introducirse en algunas fructíferas discusiones entre descriptivistas y antidescriptivistas en relación con la adscripción de un significado (o no) a un nombre propio, y a cómo se fija su referencia, cuestión que fue abordada en trabajos anteriores, y que por cuestiones de limitaciones espaciales no podré incluir. 
torno al cambio de nombres. Por un lado, retomamos la postulación de la identidad necesaria entre nombre-sentido-referente. Un signo (nombre) singulariza (sentido no descriptivo) a un personaje (referente); aunque se admita la posibilidad, como señala Frege, de que haya más de un signo para un solo referente (27). Claro está que las teorías clásicas de los nombres propios (Frege, Kripke, Russell, Searle, Strawson) tienden, por obvios motivos, a la postulación de invariancia del referente, aunque admitan la posibilidad de múltiples signos y múltiples descripciones asociadas a éstos. Esto es, hay una preocupación lógica por el problema de la identidad entre signo y referente. Ahora bien, si atendemos a la suplementariedad nominal presente en ciertos textos, lo que se evidencia es un desajuste, un desfasaje entre el signo y el referente: señalamos incluso que dicha invariancia referencial (necesaria, en un punto, para la filosofía del lenguaje) se encuentra puesta en paréntesis. Esto es porque, si el signo no queda inmodificado ¿por qué el referente (en nuestro caso, el sujeto-personaje) habría de permanecer idéntico a sí mismo? y ¿no es quizás una modificación del referente-sujeto también susceptible de reclamar para sí un suplemento nominal? De hecho, si abonamos a la idea heideggeriana del lenguaje como casa del ser y morada del hombre (o mejor, del ser humano), este problema en apariencia lingüístico adquiere dimensiones filosófico-subjetivas. Y, por eso, elaboramos la hipótesis de que los desplazamientos, sobreimpresiones y deformaciones nominales que rastreamos en los textos somersianos no son a-significantes y más bien escenifican traslaciones subjetivas en los personajes. De modo que postulamos una identidad inestable y sujeta a mutación, en consonancia con las ideas posmodernas enunciadas.

Para proponer una herramienta analítica abordamos, entonces, la perspectiva de Peter Strawson, para quien la función del nombre desde el plano pragmático es la de una expresión con "uso referencial singularizador” (61), junto con los pronombres demostrativos, personales y las frases con artículos definidos. En ese sentido, un nombre propio cumple dicho rol pragmático cuando delimita y singulariza a su referente, al mismo tiempo que establece una relación de atadura recíproca entre ambos. Aunque para Strawson la categoría de "nombre" en 
CATEDRAL TomadA: Revista de crítica literaria latinoamericana / Journal of Latin American Literary Criticism

El nombre propio como modulador de vínculos sexo-afectivos y genealógicos en las novelas de Armonía Somers: una poética de la suplementariedad nominal

abstracto carece de significado descriptivo, su uso particular, sin embargo, aparece "gobernado por convenciones ad hoc para cada conjunto particular de aplicaciones de la palabra a una persona dada" (81). De modo que, para dar cuenta de las alteraciones subjetivas en los personajes, nos resulta provechoso indagar sobre la ocurrencia (o no) de modificaciones descriptivas cuando se adoptan nuevos nombres, es decir, a partir del establecimiento de un vínculo inédito entre el nuevo signo y el referente. Consignaremos, de esta manera, aquellas novedosas convenciones ad hoc que resulten de la suplementariedad nominal, y consideraremos si el nombre nuevo porta, en efecto, un renovado abanico de convenciones ad-hoc, distintas de la del nombre previo, o no. Si esta renovación o modificación sucede de forma concreta, pensaríamos en un doble movimiento en que tanto el nombre como el referente han sido objeto de una transformación.

La suplementariedad nominal se sujeta en los casos que consideraremos a un devenir temporal -aunque no se excluya alguna simultaneidad-, al juego plástico del tiempo pero, fundamentalmente, a las modificaciones en la autofiguración de los personajes y en cómo son percibidos por otros. De modo que el nombre y su suplementariedad son elevados a la categoría de modulador subjetivo.

\section{Los nombres y La mujer desnuda (1950): preliminares sobre el plano simbólico-etimológico ${ }^{6}$}

En La mujer desnuda (en adelante: $L M D$ ) los nombres propios se presentan en una corriente fluida, más o menos continua, de adiciones y sustituciones. ${ }^{7}$ Los

${ }^{6}$ En algunos casos es necesario considerar el plano simbólico, literal o etimológico de los nombres. Si bien estos dominios exceden incluso enfoques como la teoría lingüística descriptiva (que abona a la idea del nombre como depositario de un contenido descriptivo dado por la "unicidad" del referente), por su carácter interpretativo y el riesgo de reposiciones no pertinentes; son, en efecto, epifenómenos de la suplementariedad que están tematizados en los textos, y como tales, no pueden ser soslayados.

${ }^{7}$ Uno de los antecedentes críticos importantes en relación con estos "otros yoes" (nominales) que performa la protagonista, Rebeca Linke, es el trabajo de Ana María Rodríguez Villamil. Allí, la autora aborda, en línea con su consideración de los elementos fantásticos de la obra, la "multiplicación" de personalidad(es), en que Rebeca Linke se reproduce y "multiplica" en otras mujeres (91). 
nombres se renuevan a la par del trayecto lineal que la protagonista móvil y nómade realiza. El primero de los nombres con que se denomina a la protagonista es "Rebeca Linke", que se encuentra asociado a las descripciones ad hoc de un yo desmarcado, desmemoriado y casi sin pasado $^{8}$. A causa de ello, ella adopta diferentes nombres y diversas cualidades y caracteres de mujeres "míticas" de la cultura universal. Es decir, se "auto-inviste" de figuras femeninas ancestrales a partir de la nominación. El nombre "Rebeca Linke" hace referencia, como indica Núria Calafell Sala (Armonía Somers: por una ética de lo excéntrico 31) al Nombre-Del-Padre lacaniano, al nombre "legal" que la inscribe dentro de una genealogía familiar. No es sólo el nombre dentro del cual interviene la ley paterna, que frena el goce, sino también el nombre social, que ancla a la protagonista en su linaje, su clase social y sus circunstancias específicas heredadas. Cuando la protagonista llega a la casa de campo -y antes de empezar la resubjetivación de tipo simbólica- sucede un hecho fantástico: Rebeca Linke se decapita y su cuerpo pasa a estar conformado por dos fragmentos desmembrados: la cabeza y el resto del cuerpo. Nombra a su cabeza "Amanda" y declara que quiere besarla, de modo tal que dicho apéndice corporal, que hasta entonces estaba innominado, se vuelve depositario de amor y/o erotismo por parte del resto del cuerpo ${ }^{9}$ y adquiere un nombre en el acto mismo de ser nombrado. Aunque el desdoblamiento es momentáneo, el otorgamiento del nombre "Amanda" tiene aquí un rol "referencial singularizador" (Strawson 61) estereotípico pero, al mismo tiempo, inaugural, porque se trata de singularizar aquello que estaba indiferenciado, y no de reeditar el signo existente de un referente determinado.

Un primer señalamiento es que son innegables ciertos tintes simbólicos y etimológicos que impregnan los nombres a lo largo de la novela (como también sucede en Sólo los elefantes encuentran mandrágora y Viaje al corazón del día), y

8 "Treinta años. Dejó su vida personal atrás, sobre una rara frontera sin memoria" (Somers 24).

9 En ese sentido, podemos aludir a la etimología de "Amanda", no como un factor explicativo y hermenéutico, sino como un eco antiguo de significaciones que se tejen en su sustrato lingüístico pre-nominal y que se correlaciona con la forma de dicho nombre de intervenir en la novela: proviene del latín Amandus, gerundio del verbo "amar". De modo que es "la que debe ser amada" o "la que será amada". 
CATEDRAL TOMADA: Revista de crítica literaria latinoamericana / Journal of Latin American Literary Criticism

El nombre propio como modulador de vínculos sexo-afectivos y genealógicos en las novelas de Armonía Somers: una poética de la suplementariedad nominal

que éstos -en mayor o menor medida- están tematizados en el texto, tal como señaló Rodríguez Villamil. Precisamente, la protagonista adquiere una nueva serie de nombres propios a partir del acto de desnudarse y de la interacción con uno de los aldeanos, Nataniel, en su cama. El leñador la llama “Antonia”, confundiéndola con su esposa, frente a lo cual ella replica:

Las hembras no deben llevar nombres que volviéndoles una letra sean de varón. Los verdaderamente femeninos son aquellos sin reverso, como los míos - dijo la extraña manteniendo el cálido secreteo sobre su oreja. ¿Cuáles, que yo sepa? [...]-Eva, Judith, Semíramis, Magdala. Y un hombre que soñó con mi pie, que le excedía en siglos, me llamó Gradiva, la que anda. (Somers 27) (Los subrayados son míos)

Todos estos nombres nuevos con los que la anterior Rebeca Linke se nombra a sí misma no son virginales, ni están despojados de densidad simbólica. Si bien en el fragmento citado no se aprecia -aunque se adelanta en la identificación de Rebeca con la Gradiva de la literatura-; la protagonista apela, para nombrarse, de nuevo a mujeres que han anidado en el acervo simbólico social. Y en ese sentido produce una suerte de invocación: se auto-inviste de caracteres y tonalidades de dichas figuras míticas, históricas, religiosas y literarias que, según ella, harían surgir o revelarían en simultáneo distintas cualidades reprimidas del "ser femenino", como un sustrato que está en sombra ${ }^{10}$.

${ }^{10} \mathrm{La}$ protagonista despliega esta concepción de tipo singular, aunque esencialista, del género femenino. Luego de que el leñador Nataniel usa el vocativo de "Antonia", la protagonista responde: "-Si me tocaras sabrías que soy distinta. Si me aspiraras los cabellos, las axilas, verías que somos por todas partes dos mujeres" (28). De modo que habría una dualidad opositiva existente en las mujeres. Si bien esta noción no agota la proliferación subjetiva y nominal de $L M D$, constituye uno de sus esquematismos: lo social-individual; lo moral-sexual, lo visible-lo oculto, etc. Nos referimos al desdoblamiento narrativo -codificado- que ocurre entre la mujer moldeada por la sociedad, trabajadora, asexuada, domesticada, educada en una moral, "vestida" (y por tanto culpógena), sometida y quebrada: Rebeca Linke, Antonia, la esposa de Juan y el resto de las aldeanas. Y por el otro lado, la mujer primigenia, mítica, arquetipo, amoral, deseante y deseada, que ejerce su libertad, nómade y transgresora (Eva, Semíramis, Magdala, Gradiva, Judith, Friné, etc.). 
El primer nombre de la sucesión que evoca, "Eva", está ligado a nivel temático con la mujer primigenia en el mito bíblico y el amor "original” del hombre, y se inscribe, como veremos, en las operaciones de desacralización (o desmontaje) de las figuras y motivos religiosos que se evidencian en la narrativa de Somers en general. Si bien lo sacrílego suele emplearse como factor de revulsión literaria, en la versión alternativa que presenta $L M D$, parecería más bien haber una desterritorialización (Deleuze y Guattari 9) que cambia el signo de la figura de Eva. Se trata de un gesto de vuelta al estado anterior -su "ausencia de vestidos o Unbekleidetheit"11 (Agamben 84)-, previo al sentimiento de culpa por su desnudez. Entonces, en esta Eva coexiste la inocencia -se libera de la culpabilización a la que fue sometida en la tradición judeocristiana- y la desnudez junto con el "conocimiento" de la sexualidad (erótica) ajena a los fines procreativos bíblicos (“Sed fecundos y multiplicaos”), la corporalidad y el impulso autoexploratorio. Esa condensación incluye, entonces, dos temporalidades antitéticas: la "ausencia de vestidos" (Agamben 84) e inocencia y la posterior desnudez junto con el conocimiento y la sexualidad (erótica). De modo que en esta remake intertextual del mito se resignifica la desnudez como factor subversivo del orden religioso, al tiempo que se desarticulan los motivos de castigo moral hacia la "primera mujer". El personaje que explicita esto es un oficiante de la iglesia, el cura; quien pone en duda el dogma a la vez que entra en un devenir-artista. Durante el sermón, anuncia:

Ella ha vuelto, sencillamente, puesto que ahora sabe que Dios quería que comiera del fruto. Y la mujer desnuda está de paso por la aldea, en busca de la revisión del juicio. Y se burla de vosotros y de vuestras pobres mitades femeninas, prolijamente presentadas, pero incapaces del amor entero[...] Oh, aunque ella tampoco es solo mujer. (Somers 73) (Los subrayados son míos)

${ }^{11}$ Giorgio Agamben señala que para la signatura teológica: “antes de la caída, ellos (Adán y Eva), aun sin estar cubiertos por vestido humano alguno, no estaban desnudos: estaban cubiertos por un vestido de gracia que se adhería a ellos como un hábito glorioso" (83). 
La manzana mordida que reaparece en $L M D$, como elemento intertextual, y nexo simbólico con el Génesis, ya no es signo de pecado, sino de corporalidad: el hambre como indicador fisiológico. Se hace una referencia a una conexión temporal de circunstancias que se repiten y que están ligadas al texto bíblico. "Eva" se refiere a cómo "la serpiente quiso volver a intentar la sucia historia de la fruta. Eran las mismas cosas de antes, de cuando yo les pertenecía” (Somers 27). Allí habría algo de la re-vuelta kristeviana que Calafell Sala (Armonía Somers: por una ética de lo excéntrico 31) enuncia, en el sentido de que se reexamina (y reedita) el mito fundacional. Por otra parte, Eva no es sólo la primera "mujer desnuda" sino que es el original de todas las copias, derivas y encarnaciones.

A propósito de "Semíramis", la reina asiria, y "Magdala" (María Magdalena), Rodríguez Villamil señala que su propiedad distintiva es la libertad sexual; y que el nombre "Magdala", lugar de origen de María Magdalena, sería un modo de llamarla de acuerdo a su actividad previa al arrepentimiento: la prostitución (Rodríguez Villamil 54). Esta cualidad, compendiada en dichos nombres, ocasiona que la protagonista se imbuya del goce sexual y se oponga, abiertamente, a la moral aldeana. Por otra parte, habría que agregar que Semíramis -además de ser gobernante absoluta del imperio asirio- era, según la leyenda, hija de una diosa con cara de mujer y cuerpo de pez llamada Derceto que la abandonó en el desierto para que muriera; y por eso estuvo al cuidado de unas palomas y luego de un pastor. Es decir, en este relato legendario, Semíramis tuvo que deambular en la intemperie, y ese nomadismo forzado la enfrentó a la hostilidad del ambiente. Aunque invirtiendo el signo negativo, la protagonista de $L M D$ encarna la misma actividad. La diferencia estaría que aquello que para Semíramis se origina en un abandono parental y en una circunstancia de peligro de la vida, para la protagonista de $L M D$ es una liberación sexual y respecto de la moral, a partir de la desnudez y del trayecto que camina a la intemperie. Aunque -por supuestosufre de los mismos peligros de muerte por la incomprensión de los aldeanos. Y de hecho, termina perdiendo la vida. Judith, por otro lado, es la heroína bíblica que le 
cortó la cabeza al general asirio Holofernes para salvar la ciudad de sus ejércitos (Rodríguez Villamil 91). De allí se extrae el gesto de la decapitación con resultado favorable (una "salvación" en el texto religioso, un acto de despojo, liberación moral y renacimiento en Rebeca Linke).

Por otra parte, "Gradiva" es el único nombre de la secuencia que no se liga con una figura bíblica o mítica sino literaria -aunque se podría adscribir a una especie de mito moderno, vía lectura de Freud, de la novela Gradiva: una fantasía pompeyana del escritor alemán Wilhelm Jensen. ${ }^{12}$ Gradiva era la amiga amada de la infancia y olvidada en su juventud, sustituida por los estudios de arqueología del protagonista. El análisis de Freud concluye con que el problema subyacente y que dio lugar a toda esta construcción por parte del joven es la represión del impulso amoroso, del erotismo. Se trata de la idea de lo familiar reprimido, que se condensa en la figura de Gradiva: el objeto de deseo enterrado en la subjetividad, que se reactualiza luego de haber estado latente por bastante tiempo. Es allí que Rodríguez Villamil identifica uno de los núcleos temáticos estructurantes de la novela: la sexualidad oprimida. Si Gradiva condensa el objeto de deseo reprimido, de un modo similar la protagonista de $L M D$ se erige como aquella que evidencia la represión sexual de los sujetos aldeanos, hace emerger los deseos latentes, pero sobre todo, destapa los miedos y la violencia feroz de los pueblerinos. De modo que el nomadismo de la protagonista (compartido con Gradiva), que implica "ser vista" por los aldeanos, sumado a los encuentros eróticos que ella mantiene, ubican el foco narrativo sólo en parte en su propio deseo amatorio, puesto que tiene una función de catalizador del Deseo general. Entonces, gran parte del énfasis está en el deseo del otro (el sujeto aldeano).

Por último, debemos referirnos al último suplemento nominal que la protagonista adopta: "Friné", lo cual ocurre en su encuentro afectivo con Juan.

\footnotetext{
${ }^{12}$ Rodríguez Villamil resume el argumento: un joven arqueólogo se siente atraído por un bajo relieve que representa a una joven en actitud de marcha, levantando el pie en el andar. La bautiza con el nombre de Gradiva, la que anda, y concluye que debe ser una pompeyana. Se encuentra, sin saber muy bien cómo, buscándola entre las ruinas de Pompeya y finalmente la encuentra (sin saber si es real o no) (25).
} 
CATEDRAL TomAda: Revista de crítica literaria latinoamericana / Journal of Latin American Literary Criticism

El nombre propio como modulador de vínculos sexo-afectivos y genealógicos en las novelas de Armonía Somers: una poética de la suplementariedad nominal

Nuevamente el nombre "Friné" remite a una figura en este caso histórica, se trata de una hetaira (o cortesana) griega reconocida por su belleza y por ser modelo del escultor Praxíteles. Al ser acusada de impiedad, fue enjuiciada, y la única forma que encontró el artista para salvarla fue desnudarla ante el tribunal aduciendo que no se podía privar al mundo de su belleza. Y de tal forma fue absuelta. De este modo, siguiendo con los contenidos simbólicos que impregnan la novela, se evidencia el desplazamiento valorativo respecto de la desnudez en los discursos evocados: de su condena bíblica (en "Eva") hasta su uso como forma de remisión jurídica en el mencionado discurso histórico. El significado cultural de la desnudez está sujeto a una regresión cultural (del Cristianismo hacia la Antigüedad Griega, precisamente el siglo IV a.C.), que se alinea con la trama significante y valorativa en torno a la desnudez que la novela despliega, escindida de la moral sexual y religiosa.

\section{Los suplementos nominales y sus convenciones ad hoc en $L M D$}

En primer lugar, para dar cuenta de los desplazamientos descriptivos que ocurren en la cadena de la suplementariedad nominal de la protagonista, debemos diferenciar entre dos tipos de convenciones o descripciones ad-hoc con las que se asocian: aquellas que le adosan exteriormente los aldeanos, y aquellas que ella aplica a sí misma. Si Rebeca Linke aparecía como un personaje sin atributos y casi sin memoria, por el contrario, Eva-Judith-Semíramis-Magdala-Gradiva-Friné es asociada con la descripción definida de "mujer desnuda", por parte de los pueblerinos. A pesar de tratarse de una descripción genérica, parece cobrar el estatuto de nombre propio en el ámbito comunitario en virtud de dos hechos: porque funciona como expresión con función referencial singularizadora y porque ata, en esas circunstancias y de forma contingente, el nombre a un referente, en el marco de una distribución de las subjetividades narrativas. Sin embargo, al ser, en términos de Saul Kripke, un “designador no rígido o accidental” (10), no cuadraría por tanto en su definición de nombre, puesto que éste debía ser un "designador rígido" (10). Claramente esa doble pertenencia de la frase "mujer desnuda": al 
campo de los nombres contingentes y al de las descripciones mostrativas o ad-hoc, se relaciona con el carácter externo de dicha forma de subjetivación, en que el sujeto aldeano como colectivo nombra (singulariza) y al mismo tiempo describe a la protagonista con la misma expresión. ${ }^{13}$ La protagonista irrumpe en las prácticas morales aldeanas y escandaliza en su doble y paradójica valencia referencial: “¡La mujer desnuda! Había vuelto a cobrar su primitivo nombre, impúdico, obscenamente descubierto" (Somers 103).

En el caso del nombre "Eva", como hemos señalado, el componente simbólico y religioso es muy pregnante. Se apela tangencialmente a ciertos caracteres de la tradición proustiana-metafórica recuperada por Roland Barthes ${ }^{14}$, pero no desde un aspecto de motivación intrínseca del signo, fonética, ni tampoco como "reminiscencia" individual. ${ }^{15}$ En lugar de eso, se trataría de un caudal de memoria simbólica y fundacional de la cultura occidental. En ese sentido, el uso referencial singularizador del nombre "Eva" se vuelve lábil y dudoso en el sentido de que no individualiza sino que, en ese aspecto, tiende hacia la fusión con el mito, bajo cierta forma de reactualización. La falta de unicidad o de singularización no está asociada a los potenciales miles o millones de veces que se puede usar el nombre, sino a este uso particular casi asimilador. Aquello no quita que se introduzcan torsiones respecto de la figura mítica, tanto por parte de la protagonista como por parte de sujetos aldeanos, y no pueda afirmarse que es una copia exacta de su precursora sino, más bien, una versión alterada o nueva. Sin embargo, no es menor que el signo mítico "Eva" aparezca asociado a descripciones mostrativas

${ }^{13}$ Es importante notar que aquella descripción-nombre, extrapolada a otra circunstancia, sería el estandarte de la indefinición, en tanto todas y cada una de las mujeres pueden estar desnudas; aunque en este universo textual la protagonista es la "mujer desnuda", por su unicidad referencial y porque despliega su desnudez sobre el espacio comunitario.

14 Según Barthes, el nombre propio tendría tres propiedades: "el poder de esencialización (puesto que no designa más que a un solo referente), el poder de citación (puesto que se puede convocar a discreción toda esencia encerrada en el nombre, profiriéndolo) y el poder de exploración (puesto que se "desdobla" exactamente un nombre propio como se hace con el recuerdo)" (176).

15 Esto es porque no cumple el rasgo de "esencialización" (ya hay "Evas" previas, y en particular, la original bíblica), pero sí la propiedad de "citación" (se convoca repetidamente aquella "esencia" -la copia o reversión de la Eva bíblica podría pensarse en estos términos-) y también la de la "exploración" que indica el desdoblamiento del nombre tal como se da en el recuerdo. 
CATEDRAL TomAda: Revista de crítica literaria latinoamericana / Journal of Latin American Literary Criticism

El nombre propio como modulador de vínculos sexo-afectivos y genealógicos en las novelas de Armonía Somers: una poética de la suplementariedad nominal

prototípicas de dicha figura cultural. ${ }^{16}$ Se evidencia, entonces, que se trata de un agenciamiento simbólico (y no sólo intersubjetivo), que tiende a la desubjetivación y que se replica en los demás nombres con los que la protagonista se presenta ante el leñador, Nataniel: Semíramis-Magdala-Gradiva-Judith-Friné.

Sin embargo, y más allá del efecto resultante de desubjetivación que se vuelve primordial, las modificaciones subjetivas e intersubjetivas que entraña la suplementariedad nominal suman nuevas caracterizaciones, descripciones mostrativas o ad hoc (externas a la protagonista) que exceden a los caracteres estandarizados de la Eva prototipo. De hecho, a esta protagonista que se autonomina Eva, Judith, Magdala, Semíramis y Gradiva se la describe como una "hembra soñada" (Somers 32), "fiera desnuda" (56), "mi linda, mi querida perra de juventud, mi puta dulce de otros tiempos" (37), "una mujer desnuda por completo, con voz dulce y pelo suelto" (49), con "uñas rojas y cuello fino" (49), la que "tampoco es sólo mujer" (73). Los niños la llaman "el hada de las chispas" (85). Aquellas descripciones son radicalmente disímiles respecto de la presencia desmarcada o sin acontecimiento de la anterior Rebeca Linke; y se erigen en apreciaciones colectivas y externas (excepto las de Nataniel y las de Juan), que dan cuenta de la inauguración (o reinvención) de un aspecto "sexual", de su deseo carnal explícito, de la desnudez y la transgresión. Éstas se alinean con las invocaciones de Magdala, Semíramis y Eva. La protagonista también está adscripta a algo "de otros tiempos", de la "juventud", lo cual parece cifrarse en el nombre "Gradiva": aquel deseo reprimido que se había olvidado y vuelve (lo cual se relaciona con la lectura de Freud de la novela de Jensen). Está, por otra parte, animalizada: es "fiera" y "perra", puede ser atemorizante ${ }^{17}$ y estar embebida de una sexualidad animal, porque penetra los universos oníricos y fantasmales del pueblo:

16 Las que refieren a la Eva bíblica, esto es, las menciones de la "manzana mordida", de la "desnudez", la "serpiente" e incluso la asociación directa entre la Eva carnal y la bíblica dentro del sermón del cura.

17 En ese punto, la protagonista es considerada por los aldeanos un peligro porque escenifica la liberación sexual femenina dentro de una comunidad patriarcal que somete sexual $\mathrm{y}$ económicamente a las esposas. 
es aquella que es "soñada" y que despierta los deseos reprimidos de los aldeanos (y también su violencia).

Por otra parte, el carácter nómade que adquiere la protagonista $^{18}$ y la inaudita fuerza de transgresión genérica asociados a los nombres "Judith" y "Gradiva" no están compendiados formalmente como descripciones lingüísticas mostrativas del referente nominal, tal como ocurría con los anteriores. Más bien, aquellas traslaciones subjetivas tienen asidero en el plano de las acciones narradas. Su cualidad de la "Judith" bíblica está, por ejemplo, en liberar al caballo de su rastra y generar pasmo colectivo por lo "hombruno" (Somers 43) del gesto, y también en el acto de auto-decapitarse. El carácter de ser "la que anda", la Gradiva, que parte de un bajo relieve $-\mathrm{y}$ por tanto, una figura estática-, se pone ya en movimiento desde su trayecto en tren, y se acentúa en los tres días de marcha ininterrumpida a pie.

En un tercer momento de suplementariedad nominal, la mujer hace un doble movimiento: al llegar a la casa de Juan del otro lado del pueblo nombra "Grisalba" a la perra de la familia y a sí misma "Friné". Cuando Juan pregunta por su nombre, ella responde: “—¿Yo? No lo sé muy bien. Mírame, mira cómo me hallo, Friné, creo que es así. Podrías adoptarlo desde ahora como yo he adoptado lo de Grisalba" (Somers 93). Es decir que Friné aparece como una nueva marca nominal que se origina en la transacción intersubjetiva que ocurre en el momento del intercambio con Juan. Por otra parte, a partir de la figura histórica de Friné, es posible delinear un cierto simbolismo en relación con la gracia física y cierta cualidad de musa, no ya artística sino más bien amorosa: es aquella que "inspira amor", lo cual no se evidencia con descripciones mostrativas, pero sí con promesas -o sea, actos performativos- que le hace $\operatorname{Juan}^{19}$. Las descripciones que están asociadas al signo "Friné", son ahora bastante disímiles a las de sus nombres previos. Se trata de una

\footnotetext{
${ }^{18} \mathrm{Al}$ adquirir los suplementos nominales Eva-Judith-Semíramis-Magdala-Gradiva, la protagonista comienza un trayecto a pie a lo largo de tres días por el bosque y la pradera.

19 "Las mujeres de acá no interrogan así, y uno acaba primero no prometiéndoles y luego no haciéndoles nada. Pero si tú quisieras saberlo - continuó- yo viviría alcanzándote cosas y más cosas. Tú me lo pedirías todo y yo te obedecería sin olvidarme, sin cansarme. Y muchas otras que no me pidieses" (Somers 99).
} 
CATEDRAL TomAda: Revista de crítica literaria latinoamericana / Journal of Latin American Literary Criticism

El nombre propio como modulador de vínculos sexo-afectivos y genealógicos en las novelas de Armonía Somers: una poética de la suplementariedad nominal

mujer que siente dolor (el dolor de la vida); según Juan es una "mujer herida" (Somers 96), una mujer que está "enferma, imaginando locuras, cosas que no tienen sentido" (96).También le atribuye audacia y se la considera una mujer amada.

En el plano intersubjetivo hay un agenciamiento amoroso y transformador, basado en tópicos de la enfermedad y del cuidado. De modo que, en este vínculo, más que el deseo erótico y la impotencia -como con el leñador Nataniel-, se juega el amor y el sufrimiento de esos yoes: experiencias fundacionales de la subjetividad que, por otra parte, son mucho más concretas, corporales y afectivas en contraposición al erotismo idealizado en que participaban, en mayor o menor grado, los suplementos previos (Eva, Judith, Magdala, Semíramis y Gradiva).

Por otra parte, la subjetividad sigue siendo mutable y sustituible, aún dentro de un mismo agenciamiento amoroso, los nombres propios siguen rotando:

Yo no me llamo como te dije, aunque quizás lo fuese así y de muchos modos, porque sería en ti todas las mujeres que tu irías sustituyendo noche a noche a un nombre sencillo y vulgar como deseabas, pero de mujeres verdaderamente amadas. (115) (Los subrayados son propios) $)^{20}$

De hecho, los desplazamientos de nombres no se detienen: en el momento en que Juan va a morir, el nombre Friné se sustituye por el silencio, la ausencia nominal: "ya no recuerdo cómo te llamabas" (114). El silencio ensaya una utopía de desubjetivación.

Como sugerimos, los suplementos nominales no parecen una creación espontánea, más bien surgen y ocurren en el espacio intersubjetivo, en el contacto con alguien más. No parece haber una necesidad de un(os) nombre(s) previo a un encuentro con el otro. Además, los vínculos que retrata la novela son inaugurales, nuevos (Rebeca Linke empieza su viaje despojada de todos los anteriores), y se

${ }^{20}$ Este nombre de su amada que Juan sustituiría de "noche a noche" a uno "sencillo y vulgar" que ordene y normalice, no parece una imposición sino más bien una concesión de Friné. 
yerguen en el presente, como la semilla de amapola que le crece a la protagonista en el antiguo lugar de su cabeza, en el principio. La protagonista deviene otra(s) en el mismo momento en que cambia el interlocutor. De modo que cuando Eva, al principio, dice querer ver "cómo seríamos en ti (en Nataniel) las mujeres intactas que me habitan" (27), se reconoce la potencia de transformación que el otro puede efectivizar; se manifiesta esa ipseidad del sí mismo descripta por Ricoeur, ${ }^{21}$ que implica la alteridad en un grado muy íntimo. "Ser en ti" es "ser en los otros" y, por tanto, esa construcción identitaria se realiza en el espacio intermedio en que dos subjetividades se encuentran.

\section{Los nombres y Sólo los elefantes encuentran mandrágora (1986)}

En Sólo los elefantes encuentran mandrágora (en adelante: SLEEM) la forma en que los suplementos nominales habilitan nuevas posibilidades vinculares difiere respecto de $L M D$ : no se trata primordialmente de una inauguración de vínculos inéditos -aunque en algún caso sí suceda-, sino de la reedición de las líneas conceptuales de parentesco. En $L M D$ el despojo de la memoria y de las configuraciones relacionales previas de Rebeca Linke genera un arrojo narrativo a un presente: sus acciones se fundan entre el siendo y el porvenir, el enfoque es prospectivo y está casi exento de pasado. Además, se trata de agenciamientos subjetivos fundados en el deseo y en la reinvención recíproca del sí y del otro, en mayor o menor medida. En el caso de SLEEM, la suplementariedad nominal -que es, por cierto, sólo un recorte dentro de todos los movimientos subjetivos que ocurren al interior del texto- implica, a grandes rasgos, un señalamiento, una multiplicación e incluso una reformulación de las líneas genealógicas en que se inscribe la protagonista, Sembrando Flores.

${ }^{21}$ Paul Ricoeur introduce la consideración de una identidad dinámica, narrativa, indisociable de la temporalidad, y por tanto, de la alteridad, como un movimiento pendular entre la mismidad (lo idéntico a sí mismo) y la ipseidad (el ipse del latín, el sí mismo que sufre modificaciones a lo largo de lo narrado). Esta noción permite considerar la mutación, el cambio y lo Otro, como una parte constitutiva de la identidad (107). 
En primer lugar, uno de los motivos narrativos fundamentales de la novela, que sirve de piedra angular para la consideración nominal, es la búsqueda de la mandrágora. Sirviéndose de la Botánica oculta de Paracelso, las voces narrativas reconstruyen parcialmente la mitología alrededor de esta planta considerada mágica. Se enuncia que la mandrágora tiene una raíz muy parecida a la figura del hombre y que "ciertos místicos ven en ella el vestigio umbilical de nuestro origen terrestre" (Somers 124). Además, como se supone que el hombre, al principio, tenía forma de raíz, se sigue que "los primeros hombres eran de la familia de la mandrágora" (Somers 124). De este modo, la preocupación por encontrar la mandrágora implica en la novela una búsqueda del origen, que se revela como imposible en su acepción de unicidad. Al estar sujeto a desplazamientos y suplementariedad, se produce un estallido de múltiples orígenes que son irreductibles. Esto es porque los nombres propios y los suplementos nominales que se adoptan son señuelos de aquella adscripción a orígenes diversos, que exceden los vínculos de sangre. Estos nombres no se emplean sólo para señalar y multiplicar aquellos linajes, sino también para reeditarlos y producir reinscripciones dentro de otros más amplios: familiares, ideológicos, literarios y médico-científicos, que están, en muchos casos, superpuestos. Las reediciones de las líneas parentales en el plano nominal (aunque no sean las únicas) son, a diferencia de $L M D$, retrospectivas. Reformulan el pasado y por ende, implican movimientos subjetivos genealógicos.

Mientras Rebeca Linke era un agente activo en términos de adoptar y otorgar suplementos nominales, Sembrando Flores -con algunas excepciones- se posiciona como receptora de nombres. Por otra parte, en $L M D$ la suplementariedad nominal se produce en el marco de una continuidad temporal que se proyecta al porvenir pero que, no obstante, admite una poli-nominalidad: Rebeca Linke adopta cinco nombres al mismo tiempo (Eva-Judith-Gradiva-Magdala-Semíramis); por el contrario, en SLEEM, la coexistencia o simultaneidad de los suplementos nominales es un efecto de la amalgama textual en que el tiempo está desarticulado, en especial en las alternancias entre "Sembrando Flores" y "El caso". Es muy importante, en ese sentido, el señalamiento de María Cristina Dalmagro respecto al 
uso de los nombres "Sembrando Flores" y "Fiorella". Cada uno remite a un momento diferenciado de la vida del personaje: el primero se asocia la adultez y el segundo, a la infancia en el campo (Desde los umbrales de la memoria: ficción autobiográfica en Armonía Somers 184).

La primera línea de parentesco para considerar es la literaria. En la ficha clínica de la protagonista se anuncia su descendencia literaria "bilateral”. “Antecedentes familiares: novelísticos. Nieta literaria por vía materna del escritor español Enrique Pérez Escrich. Y por la paterna, del autor de la novela Sembrando Flores, el librepensador también español Federico Urales" (Somers 16) (Los subrayados son propios). Se reproduce, de esta manera, una suerte de mito de origen estructurado sobre metáforas genealógicas: es "nieta" conceptual de estos novelistas. Por ello, Sembrando Flores forma parte de una segunda generación que se reidentifica con los relatos fundadores de subjetividad de los padres. La literatura entonces, provee de identidad en cadena y se pliega, asimismo, sobre identificaciones ideológicas: el legado paterno está signado por la literatura y el anarquismo, y se materializa bajo una forma lingüística nominal (y alusiva), "Sembrando Flores"; y el materno, sin contraparte nominal, se caracteriza por la literatura de folletín, popular, de Enrique Pérez Escrich. ${ }^{22}$

La metáfora familiar, por otra parte, se extiende a las afiliaciones literarias cuando se piensa a sí misma como "viuda" de Dante Alighieri o, más bien, de la Divina Comedia como objeto-libro personificado. ${ }^{23} \mathrm{Si}$ el nombre "Sembrando Flores", además de su genealogía libresca, también se inscribe en una tradición ideológica (un nombre-emblema de un autor anarquista), es importante identificar su contraparte, no ya política, sino religiosa, que no se instituye como suplemento nominal como tal, pero que permanece un nombre potencial: "María del Rosario", otorgado por el cura, casi al pasar. Como Sembrando Flores nació un siete de

${ }^{22}$ Si bien el legado ideológico materno no redunda en una marca subjetiva de tipo nominal, sí instituye un modo vital identitario basado en la lecto-escritura, como señala Susana Zanetti: experiencia lectorial compartida del personaje con su madre (430).

${ }^{23}$ Los libros, a partir del pronombre personal de tercera "ellos", son alteridades que se personifican -"respiran" (73) - y funcionan como fuente inagotable de nombres (y por tanto, de genealogías). Sembrando Flores y Miravalles encuentran en un libro el nombre para el gato: "Cantaclaro". 
CATEDRAL TomAda: Revista de crítica literaria latinoamericana / Journal of Latin American Literary Criticism

El nombre propio como modulador de vínculos sexo-afectivos y genealógicos en las novelas de Armonía Somers: una poética de la suplementariedad nominal

octubre, la llama como la patrona religiosa asociada a este día: quería ver si recibía alguna señal para hacer negocios con la hija de un "enemigo de la fe" (Somers 131). La puja ideológica se libra en el plano simbólico plegado sobre el nominal. También hay otro nombre "literario" para Sembrando Flores: "Dulcinea", emparentado con el Quijote de Miguel de Cervantes. Dicho nombre es otorgado por el maestro de la protagonista y perpetúa la idea de una ascendencia literaria.

En segundo lugar se encuentran las líneas de parentesco familiar. María Cristina Dalmagro señala:

Atendiendo a la primera línea de su ficha clínica, destaca la diversidad de nombres con que se identifica. Y allí no incluye los sobrenombres, apodos, o nombres sustitutos puestos por otros personajes, los cuales, en general, tienen relación con la ideología de quienes los proveen. Los dos nombres principales tienen que ver con sus genealogías. Su padre decide llamarla Sembrando Flores, y rescata en ese nombre el del título de una breve novela del anarquista español Francisco Urales. Su madre, en oposición a ello, la llama Fiorella, recuperando el sentido de libertad y frescura condensado en un término que remite tanto a las flores como a su linaje italiano. (Dalmagro, Desde los umbrales 184) (Los subrayados son propios)

De modo que el universo familiar genera un plegamiento de más de un nombre y apellido, esto es, el uso de suplementos nominales siempre sujetos a una bifurcación o como mínimo a una bilateralidad que, como indica Dalmagro, señalan líneas genealógicas diferenciadas. La protagonista se llama Sembrando Flores y/o Fiorella. Y se apellida Irigoitia Cosenza y/o Médicis. La conjunción o disyunción en el nombre de pila está dado por un otorgamiento legal, vía paterna ("Sembrando Flores"); y por otra parte, una resistencia materna a éste por su "ridiculez" y la preferencia por "Fiorella", más afín e inteligible para el lado italiano de la familia. En el caso de sus apellidos: "Irigoitia Cosenza", el primero refiere al supuesto 
apellido paterno, apócrifo, y con una "una estrafalaria historia"; y el segundo, materno, refiere al de origen italiano de la madre y a una "geografía volcánica" (55). Pero luego, el apellido "Médicis" desplaza a los anteriores bajo la forma de un suplemento en tanto apellido primigenio del padre. Más allá de la evasión de las responsabilidades penales (y del ocultamiento político) que implica la adopción de "Irigoitia", ${ }^{24}$ aquel suplemento impide, por un lado, la recreación de las cadenas genealógicas: funda un punto ciego o de pérdida en ésta en términos genéticos y biológicos. Pero por el otro lado, se funda o crea una genealogía nueva, adscripta a antecesores azarosos: a ciertos "Irigoitia".

Por la muerte "real" de Pedro Irigoitia se revela su nombre primigenio: Pedro Cosme de Médicis. En el plano más superficial se verifica un desplazamiento de nacionalidad: Los Médicis tienen origen italiano, frente al apellido Irigoitia, originario del País Vasco. Esa operación de develamiento implica que Sembrando Flores está emparentada con la célebre y acaudalada familia florentina de los Médicis. La antigüedad de dicha adscripción nominal, que pasa por "novedad" para Sembrando Flores tiene consecuencias en el mapa de distribuciones vinculares: se imbrican la emergencia de familiares desconocidos y las relaciones genealógicas hasta ese momento inéditas u ocultas con éstos. No sólo hacen su aparición en el entierro los cuatro primos del padre, sino también el otro hijo de Pedro, Liberto (medio hermano de Sembrando Flores). De modo que, en principio, hay un restablecimiento e inauguración (en términos de conocimiento, pero no legales) de aquellas líneas de parentesco que no sólo atañen a primos del padre, sino al propio medio hermano recién descubierto de la protagonista. Sin embargo, las circunstancias que propician el develamiento de la línea familiar oculta son la puja

\footnotetext{
${ }^{24}$ Pedro Irigoitia, afiliado a la FORA anarquista y participante de los choques entre huelguistas y fuerzas represivas durante la semana trágica en 1919, compra un cadáver y le asigna su propia identidad: Pedro Cosme de Médicis. Al mismo tiempo que Pedro se da por muerto, adopta, por motivos políticos, pero luego también criminales, el apellido "Irigoitia" (es responsable por la muerte accidental de un hombre). A la ilegalidad de la usurpación de identidad del muerto, se suma la de haber dado muerte a otro hombre. De modo que el suplemento nominal (cambiar Cosme de Médicis por Irigoitia) implica un enmascaramiento identitario que actúa como subterfugio frente el poder estatal y revela el nombre en su faceta de instancia de control del estado. Esta forma de suplementariedad nominal es radicalmente distinta a las que consignamos hasta ahora en Somers.
} 
CATEDRAL TomAda: Revista de crítica literaria latinoamericana / Journal of Latin American Literary Criticism

El nombre propio como modulador de vínculos sexo-afectivos y genealógicos en las novelas de Armonía Somers: una poética de la suplementariedad nominal

por la herencia económica "Médicis" rechazada por Pedro, pero deseada por sus primos. En la novela, la inscripción de Sembrando Flores y de Liberto en el linaje Médicis no puede realizarse legalmente, por ciertas manipulaciones de los primos y de los abogados. Se cumple así la amenaza de los primos de que ellos "nunca serán Médicis", de modo que no pueden acceder a la herencia. Incluso, Liberto es internado en un psiquiátrico y torturado, con lo cual concluye que prefiere llamarse "Juan Pérez" o "el gaucho Pérez" (Somers 294) y negar el robo de su herencia, a seguir atravesando dicho dolor.

Por otra parte, tenemos que aludir a la participación de la protagonista en una línea genealógica de raigambre médico-científica. En el presente narrativo, adquiere los suplementos nominales "El Caso" y "El Quilotórax". ${ }^{25}$ Frente a dicha reducción subjetiva en que, o bien es idéntica nominal y genealógicamente a la enfermedad que padece, el Quilotórax, o bien se le quita toda especificidad, todo carácter determinado, al nominarla "El Caso", la protagonista ahonda en la exposición y reedición de sus líneas genealógicas. La búsqueda del origen, de la que participa la metáfora del linaje botánico que se rastrea hasta la mandrágora, se intensifica precisamente en aquel momento del presente en que la memoria flaquea y se empantana. De este modo, se trata del momento vital en que se condensa la amalgama de subjetividades, tiempos y textualidades -que comprende la totalidad de la novela-y, como señala Barrantes, de escritura "fuera de sí" (1). Esto es porque, a nivel identitario, estos suplementos nominales ("El Caso" y "El Quilotórax") pugnan por borrar las adscripciones genealógicas previas. Esa tendencia al "borramiento" de los múltiples linajes de Sembrando Flores hacen que quede, nominal y subjetivamente, reducida a la enfermedad como dadora de identidad. A pesar de quedar, entonces, deshumanizada y desmemoriada, resiste,

${ }^{25}$ Como señala Núria Calafell Sala: "de la denominación primera -extraña por metafórica, lúdica por alusiva, barroca por excesiva- a la indeterminación del diagnóstico con mayúscula, la protagonista experimenta así la primera de las múltiples pérdidas que la acompañarán a lo largo del camino y que tendrán en el Quilotórax su máximo exponente" (Armonía Somers: por una ética de lo excéntrico 34) (El subrayado es propio). 
no obstante, con su memoria fragmentada y su "locura". Sin embargo, la adquisición de suplementos nominales no se limita a Pedro y a Sembrando Flores. ${ }^{26}$

Como señala Susana Zanetti, en SLEEM hay una focalización en la construcción de linajes que despliegan las significaciones que el lexema herencia ha tenido desde perspectivas científicas, sociológicas, culturales y literarias (432). Las genealogías o líneas de continuidad multiformes que emparentan a Sembrando Flores con su parentesco (familiar, literario, ideológico y médico) implican vasos comunicantes, líneas de continuidad ininterrumpida -de las que participan la “deglución” de las múltiples textualidades que componen la novela y la amalgama de subjetividades-. Y de este modo, se reproducen de forma paródica ciertos rasgos heredados o "inoculados" en función de los grupos genealógicos en los que ella participa.

Precisamente consideramos que el texto opera un corrimiento de lo unario y de la individualización y se aproxima a la noción de agenciamientos colectivos de subjetivación ${ }^{27}$ (Guattari y Rolnik 48) pero en este caso llevados al absurdo genealógico: no sólo a la predisposición genética (médica y familiar) sino también ideológica, pero más aún, vivencial: se heredan las vicisitudes narrativas de los antecesores familiares y literarios. Sembrando Flores no sólo contrae (según la hipótesis del texto) el Quilotórax por su madre, sino que también se apropia de la memoria materna. Recibe la herencia lectora de los folletines de Pérez Escrich, lo cual engendra un potencial creativo. Dichas novelas son "traspasadas a las memorias del feto por la sangre de la madre" (Somers 220) y "habían tenido tanta gravitación en sus fuerzas creativas como cualquier sustancia específica” (220). Sin

\footnotetext{
${ }^{26}$ Otros suplementos nominales se presentan en la amiga de la protagonista, María del Huerto, apodada como "La Caña", forma nominal que es extensible a toda su familia (Somers 16) a causa del "hábitat" en que viven: el cañaveral. Allí se conjuga la idea de clan y de medio en una nominación ilustrativa (e incluso determinista). En segundo lugar, hay que señalar tres casos de suplementariedad nominal en que la protagonista es agente activo. Nombra a aquel novio fallido "Tiberíade" (166) y a su medio hermano, Liberto, como "Espartaco". Este es el nombre que hubiera tenido Sembrando Flores si hubiera nacido varón (Zanetti 425). En ese sentido, se trata de una reinscripción del medio hermano dentro del universo nominal de su propia familia nuclear: una operación incorporativa. El último caso está dado por nombrar "Cantaclaro" al gato.

27 "La subjetividad está en circulación en grupos sociales de diferentes tamaños: es esencialmente social, asumida y vivida por individuos en sus existencias particulares" (Guattari y Rolnik 48).
} 
CATEDRAL TomAda: Revista de crítica literaria latinoamericana / Journal of Latin American Literary Criticism

El nombre propio como modulador de vínculos sexo-afectivos y genealógicos en las novelas de Armonía Somers: una poética de la suplementariedad nominal

embargo, no son sólo los textos y el hábito de leer lo que se hereda sino también todo su contexto de lectura original: la memoria de las escenas de Abigaíl y Marianna, su lectora designada. Cuando Sembrando Flores exclama, reproduciendo a Abigaíl: “¡Pobre mi hijo Escolástico!” (20), sin que sea su hijo, ni tampoco un recuerdo propio, está inscribiéndose en una extensión de la memoria de su madre. Se trata de una fagocitación subjetiva o un préstamo de memoria en que hay una doble dislocación genealógica y apropiadora: la primera instancia está dada por su madre, Marianna, testigo de los hechos, y la segunda, por Abigaíl, la autora de dicha frase. En el plano del universo literario de Pérez Escrich, se produce una simetría o "transferencia hereditaria de motivaciones" de padres e hijos. Pero esto también ocurre por fuera: en el carácter bígamo del padre de Sembrando Flores, Pedro Irigoitia, se replica la bigamia de uno de los personajes de El manuscrito de una madre: Pedro de Lostan. También hay una simetría entre el odio por las mujeres pelirrojas, heredado de la abuela de la protagonista.

\section{Suplementos nominales en $S L E E M$ y el aspecto lingüístico}

Para profundizar nuestra indagación de los nombres, resulta invaluable el aporte de Susana Zanetti, quien refiere a la dinámica creativa que entraña la "plural novelería" de éstos, abiertos a cambios y transformaciones (424). Indica, asimismo, cómo se parodia la intención de propiciar un destino a través de los nombres (425) y advierte el despliegue de su riqueza "si se renuncia a convertirlos en el punto en el cual convergen cualidades con que se han pretendido sujetar a personajes" (425). De modo que, en lugar de leer los nombres en su literalidad y en la profetización nominal de sus "destinos" -lo cual los constituye, como señala Zanetti, como “emblemas de vacuidad" (425)-, se trataría de leer dichos trazos en la parodia, pero también en su apertura a la creatividad (subjetiva). En lugar de clausurar interpretativamente a los personajes, esto permite tematizar el potencial subjetivador de los nombres propios.

Empecemos, entonces, por "Sembrando Flores". Categorialmente, y en principio, proviene de una construcción alejada del universo de los nombres propios 
-se podría pensar incluso como un anti-nombre-: es un sintagma formado por un gerundio y un sustantivo común recategorizado (como nombre) en virtud de su "uso referencial singularizador” (Strawson 61). Ese carácter foráneo y el señalamiento de su desclasificación lingüística (que hace que pervivan aún más los significados "heredados" de las categorías lingüísticas previas en el nuevo uso) producen una visibilidad radical del nombre en los diversos entornos en que actúa la protagonista, dado que es recibido en toda su literalidad y en la exacerbación de su efecto paródico. Por eso, no hay neutralidad posible en el signo. Esta operatoria tiene menos que ver con el nexo signo-referente en términos de una "descripción” única intrínseca a lo referido, y más con una forma de alusión en la que explota la plasticidad de los significantes para evocar, poetizar y parodiar esa ligazón entre signo-referente. A diferencia de $L M D$, aquí el foco no está tanto sobre una densidad simbólica de las significaciones previas sino, en parte, sobre aspectos ideológicos y, sobre todo, aspectos literales. En algún sentido es un signo "voluminoso" y "cargado de espesor de sentido" como señala Roland Barthes respecto del nombre proustiano (174). Pero si esto es posible, no es ya por su poder poético de evocación, sino por su pura literalidad amparada en la posición marginal o externa del nombre "Sembrando Flores" al sistema nominal estándar para personas/personajes. Esto es, éste difiere de cómo se presentan los nombres en general: o bien, en el caso de nombres derivados de sustantivos comunes, a partir de una suerte de "olvido" primario de su anterior significado; o bien, en nombres despojados de todo trazo de significado descriptivo, como factor de enlace con un referente. Por el contrario, en "Sembrando Flores" hay una importación, un contrabandeo de algo de ese significado descriptivo del gerundio y del sustantivo que persisten, cual fantasma, en dicha recategorización.

$\mathrm{Si}$ pensamos en las convenciones ad-hoc que vinculan el nombre de Sembrando Flores a su portadora, esas "mostraciones descriptivas" son más bien apreciaciones metalingüísticas, nominales: varios de los otros personajes juzgan aquella expresión singularizadora como extravagante: se trata de un "extraño y sugestivo nombre" (Somers 16), es un modo "rebuscado" (16) de llamarse. La 
CATEDRAL TOMADA: Revista de crítica literaria latinoamericana / Journal of Latin American Literary Criticism

El nombre propio como modulador de vínculos sexo-afectivos y genealógicos en las novelas de Armonía Somers: una poética de la suplementariedad nominal

madre de Sembrando Flores lo califica de "ridículo" (31) y opta por usar "Fiorella" en el ámbito familiar; para el cura Juan se trata de una "broma” (131); para Epifanía es un "nombre poco cristiano" (44). Sumado a todo este efecto de extrañeza, posee, por otra parte, la apertura semántica a una duración, lo cual relaciona el afiebrado presente de la protagonista con aquel Dasein de la enfermedad.

A pesar de la fuerte resistencia a dicho uso nominal, la intención de Pedro Irigoitia habría sido otorgar nombres a sus hijos:

integrando un proceso: Sembrando Flores o la utopía pura el primero. Espartaco encabezando las hordas de rebeldes hasta caer en el horripilante castigo, el segundo. Esto era ya algo más concreto que sembrar flores con destino al pisoteo de los búfalos. Y luego Liberto mismo, una convicción sin vuelta de hoja sobre el destino del hombre. (298) (Los subrayados son propios)

De modo que no sólo se pone en primer plano la herencia genealógica anarquista y paterna que motiva el nombre, sino también su lógica conjuntiva. Los nombres de los hijos tienen una existencia procesual dentro de una configuración más amplia y continua, y las identidades discretas son sólo momentos dentro de este conjunto más abarcativo. En los ejemplos anteriores se observa, grosso modo, que las descripciones asociadas al nombre quedan circunscriptas al plano nominal y dicen poco o nada sobre su portadora. Lo que se evidencia, en todo caso, es su cualidad foránea $-\mathrm{y}$ herética - dentro del marco cultural, religioso e ideológico en el que vive. Conviven con éste los sentidos metafóricos que aporta el padre: "Sembrando Flores" como un símbolo de utopía, por otra parte, parodiado. Se trata de un nombre que representa la idea de "sembrar flores" cuyo destino sería ser "pisoteadas por búfalos", cuestión que lo devuelve a sus dimensiones terrenales.

Un tercer conjunto de descripciones alude a una pura literalidad, al tiempo que a un determinismo aplicado sobre su portadora. Aquellos sentidos (del gerundio "Sembrando" y del sustantivo "Flores") son traficados a la aprehensión del nombre. 
Por ejemplo, refieren a construcciones metafóricas que parten del significado de las palabras que componen el nombre, o bien, a la pura literalidad de éste. Se dice que la protagonista "tiene un jardin en la cabeza" (159), un nombre con "flores cayendo" (108); que es un nombre "original" porque permite que cada quien "invoque su propia flor" (56). La pregunta que aparece en boca de otro personaje es ¿cómo (la protagonista) no iba a saber de flores (con ese nombre)?, por tanto concluye que éste le viene como un "traje a medida" (159).

En algún punto, el profuso conocimiento que tiene Sembrando Flores de botánica oculta da cuenta de una suerte de coincidencia entre nombre e intereses; podríamos decir que se produce - para no clausurarla como algo fortuito que describe una mera concomitancia- una suerte de invocación esotérica de los significados heredados lingüísticamente en el nombre. Si pensamos a partir de sus líneas genealógicas, su apropiación del nombre y reformulación en sentido botánico funciona, por su literalidad, también como parodia frente al nombre metafóricoanarquista otorgado por su padre. En ese sentido, es un desvío en la significación, y por tanto, en la herencia. De hecho, tal deriva se manifiesta también en una dislocación genealógica: su "padre frustrado" y primer novio de su madre, Esculapio, era boticario.

Respecto del nombre "Fiorella", como mencionamos, de adscripción materna y de origen italiano, podemos señalar que, como sustantivo común, significa "flor pequeña". De modo que se trata de una italianización -lingüística, cultural- del nombre primario, que se da en función de una especie de proximidad semántica. Pese a esto, el significado heredado del sustantivo común está sujeto a "olvido" porque se trata de un nombre prototípico, empleado como tal, y por la distancia entre lenguas (el italiano y el español). Siguiendo la hipótesis de María Cristina Dalmagro, es el nombre de la infancia y de la vida en el campo (Desde los umbrales 184), esto es, un nombre estándar, despojado de otras connotaciones no textuales. Pero además, a diferencia de Sembrando Flores, que es el nombre legal y público, se trata de un suplemento familiar e íntimo, de carácter privado, pero también en sombra. Es el nombre de la madre, de lo femenino, invisibilizado frente 
a la prominencia y rareza de su nombre "adulto". De alguna manera, el nombre "Fiorella" encarna un acto de resistencia político-nominal materna que ensaya una subversión de la ley paterna.

Pero, oportunamente, Sembrando Flores "se borró" y fue "El Caso" (16). Nuevamente, los dos nuevos suplementos: "El Quilotórax” y "El Caso”, mantienen formalmente su condición de sustantivos comunes a partir de la conservación de sus artículos, de manera que los respectivos significados importados al "nombre", como expresión con uso referencial singularizador, quedan en primer plano. "El Caso" es, sin dudas, el suplemento que mayor indeterminación, genericidad y expoliación subjetiva supone y, al mismo tiempo, da cuenta de la condición de caso único (que aquí es médico, pero podría no serlo). De modo que, en la circunstancia hospitalaria se opera una reducción subjetiva, metaforizada en el suplemento, a partir de la identificación con su enfermedad (ella es "El Quilotórax") o de su condición médica desustancializada e indeterminada ( ella como "El Caso"). Ahora bien, si atendemos a las convenciones ad hoc que rodean a estos nuevos suplementos, observamos que delinean una patologización mental. Se dice que "El Caso seguía chiflando a todas luces" (108); o que "El Caso está desvariando de nuevo", lo cual era "la forma de interpretar su realidad fantástica" (100). Se trata de descripciones exteriores que reinterpretan su "escape del safari racional" como enfermedad psíquica. Pero lo que importa, en definitiva, es el viraje en el tipo de descripciones que dichos nuevos nombres convocan: desde un nombre con reminiscencias ideológicas, literarias; marcado en su rareza y efecto paródico y como índice de una afinidad con la botánica - esto es, una exacerbación de la singularidad- hacia dos suplementos genéricos que aparecen asociados, además a la locura y una la lengua fuera de sí, en un sentido peyorativo y patologizante.

Frente a esta reducción subjetiva del aparato científico, el recorrido de la novela -signado por la "ocupación” que la protagonista reclama para sí: trabajar con recuerdos-, es un intento de restaurar aquel saqueo subjetivo y rastrear sus múltiples herencias -encarnadas, muchas de ellas, en los nombres-, para ir en la (imposible) búsqueda de un origen (o de la mandrágora) que en tanto heteróclito y 
múltiple, se dispersa y estalla en fragmentos. Frente a la desubjetivación impuesta por el dispositivo médico, se opone, como acto de resistencia, la puesta en discurso de la disolución subjetiva de la protagonista.

\section{Viaje al corazón del día (1986): configuraciones vinculares y suplementos nominales}

En la novela corta Viaje al corazón del día (en adelante: $V A C D D$ ) los suplementos nominales propician, al igual que en $L M D$, nuevos e inéditos agenciamientos vinculares entre personajes. Las configuraciones intersubjetivas que se establecen (con mayor o menor estabilidad) en $V A C D D$ son bipartitas o tripartitas y cuentan con una cierta reciprocidad. Es posible pensar que los vínculos primigenios que se plantean entre los personajes responden a la forma de un triángulo de lógica piramidal que tiene a la cabeza a la matriarca (Encarnación), cuyos dos vértices inferiores (subyugados) están sujetos a un desvío genealógico: Laurent-Macario en la posición de hijo de su abuela y Laura como hija sustituta de su tía. En relación con dicha construcción de poder sobre los cuerpos y las sexualidades que ejerce Encarnación, se presentan estos nuevos agenciamientos que socavan u horadan aquella figura de carácter piramidal rígida en que el poder se ejerce de forma unidireccional y supone una cierta inmovilidad subjetiva. Frente a ésta, los nuevos agenciamientos describen figuras más plásticas, multidireccionales y subversivas: una línea bidireccional que une dos puntos $\mathrm{a}$ y $\mathrm{b}$ (Laura y Macario-Laurent) y los pliega entre sí y, por otro lado, el trazado de figuras triangulares ajerárquicas en las que los vértices están interconectados en ambas direcciones. En el caso de ambas figuras, lo que habilitan son agenciamientos amorosos, eróticos o deseantes que se filtran entre la malla del poder represivo sobre los cuerpos y las sexualidades que impone Encarnación y, además, suponen algún tipo de subversión del dispositivo sexual (incesto y lesbianismo): afectos 
CATEDRAL TOMADA: Revista de crítica literaria latinoamericana / Journal of Latin American Literary Criticism

El nombre propio como modulador de vínculos sexo-afectivos y genealógicos en las novelas de Armonía Somers: una poética de la suplementariedad nominal

"desviados" de la norma sexual heteronormativa que incluso infringen ciertas restricciones o tabúes culturales. ${ }^{28}$

El primer vínculo bipartito -como línea plegada- en la novela se inaugura a partir del momento en que Laura provee de un suplemento nominal a su sobrinoprimo, el niño-muñeco que vive en el sótano. Lo llama "Laurent", "porque" señala- "yo soy Laura" (Somers 13). Esta transacción subjetiva se inicia a partir de una comunicación secreta con el niño por un canal de ventilación, a través del cual Laura baja y sube con un cordel, a modo de caña de pescar, unos carteles con mensajes y dibujos, y recibe otros como respuesta. De hecho, como la niña intuye de alguna manera el analfabetismo de Laurent, utiliza carteles como herramienta pedagógica: "Yo Laura, tú Laurent" (22). De modo que el acto de nominación opera como forma de colonización pedagógica del otro. Esto es, por un lado se trata de plantar una bandera subjetiva, una marca lingüística que le sirva al otro para autoreferenciarse; pero en su afán alfabetizador, también se pretende influir sobre sus marcos de referencia y su universo conceptual. Al otorgarle una identidad del lenguaje, Laura lo concibe como un ser innombrado, tabula rasa (cuando en realidad descubre tardíamente que el niño sí tenía un nombre). Por otra parte, el nuevo nombre surge a partir de una deformación y de un afrancesamiento ensayado del nombre propio "Laura". El aprendizaje del francés era para Encarnación como la "cereza abrillantada" de la educación de las niñas (21). De modo que las formas de intervención pedagógica y de colonización nominal de Laura están atravesadas por sus propias formas de cooptación educativa: “sacarían de mí un mono sabio mientras la ignorancia del ángel fuese en aumento" (21). ${ }^{29}$

${ }^{28}$ En su lectura de Freud, Judith Butler señala que aunque éste no arguya explícitamente a su favor, parecería que el tabú contra la homosexualidad debe ser anterior al tabú sobre el incesto heterosexual. De modo que, dentro del psicoanálisis, la bisexualidad y la homosexualidad son disposiciones libidinales, y la heterosexualidad es la elaboración laboriosa basada en su represión gradual (69). Esta filósofa cita a Foucault cuando señala que la noción de una sexualidad "original" (reprimida y prohibida) acaba siendo una producción de la ley que más tarde funciona como su prohibición. Si el deseo original (heterosexual e incestuoso) es por la madre, se trata de un deseo creado y prohibido dentro de ese contexto cultural (en este caso, el capitalismo tardío) (170).

${ }^{29}$ Allí se evidencia la diferencia en la impartición de la educación en cada personaje: querer "sabiduría" o conocimientos en Laura e ignorancia en el niño privado de libertad. Pero, sin embargo, la valoración de cada uno (en la percepción de Laura) es inversamente proporcional a 
Al afrancesar el nombre propio - metamorfosear "Laura" en "Laurent"-con el objetivo de otorgar un suplemento al niño, se traza una línea de continuidad que liga a Laura y Laurent en un campo de subjetividades no discontinuas en que, en términos del significante, una expresión engendra a la otra, por lo cual, más que compartimientos estancos se trata de zonas de intermediación. "Laurent" deriva del latín Laurentius (hombre de Laurentium), que vendría (como una de las hipótesis) de Laurus, (laurel) expresión de la cual deriva "Laura". De hecho esta acción prefigura otros tipos de reciprocidad que exceden la onomástica y se introducen en el campo de lo afectivo, lo amoroso.

Para Julia Kristeva, el sujeto que se adopta en el siglo XX es uno se constituye como tal -en el marco del molde epistemológico de la lingüística estructural- desde el momento en que "tiene conciencia de una significación" (249). Al construirse en la acción predicativa, tiene carácter lingüístico. ${ }^{30}$ Entonces (y quizás operando un pequeño forzamiento) la "conciencia" subjetiva que se inaugura en el niño ("Yo Laurent") al adquirir un nombre otro y al estar, a su vez, en proceso de alfabetización, en realidad ya parece -en virtud de esa filiación lingüística- predispuesta a la transacción afectiva que Laura inicia con él. Y de algún modo dicha circulación de los sentimientos consuma aquello que se encontraba prefigurado en la reciprocidad de los nombres y en la colonización nominal operada por Laura.

El agenciamiento erótico y subjetivo entre Laura y Laurent es bipartito en tanto implica plegamiento y amalgama. Desde el principio, cuando Laura imagina la existencia de Laurent en el sótano, la co-presencia intuida se imbuye de la fantasía de fusión descrita por Georges Bataille antes de haber tenido, incluso, comunicación alguna. Ella narra: "yo respiraba el aire que estaría exhalando el otro, y éramos entonces uno de cuatro pulmones, uno de dos cabezas, un ser de

su conocimiento. Laura se ubica simbólicamente en un peldaño más bajo de la escala zoológica: "un mono", frente a Laurent como ser angélico, incorporado a la simbología cristiana.

${ }^{30}$ El sujeto "construye esta conciencia judicativa, al afirmar al mismo tiempo al ser significado y por ende, al objeto del sentido y de la significación y/a la conciencia operante misma" ( Kristeva 255). 
CATEDRAL TomAda: Revista de crítica literaria latinoamericana / Journal of Latin American Literary Criticism

El nombre propio como modulador de vínculos sexo-afectivos y genealógicos en las novelas de Armonía Somers: una poética de la suplementariedad nominal

duplicación como dos estrellas que se ven tan juntas tal si fueran un modelo de réplica" (Somers 20) (Los subrayados son propios). También se evidencia este tipo de metáfora después de la consumación del amor: la autopercepción de Laura (y Laurent) como un "monstruo bicéfalo de ocho tentáculos cambiantes de lugar y forma" (73). Se trata de una animalidad conjunta, la composición de un monstruo amoroso a partir de la combinación de miembros y partes corporales que, por las figuras rarificadas y "antipoéticas" que emplea, atempera o suaviza sus rasgos melodramáticos. ${ }^{31}$ Dicha fantasía de fusión batailleana alcanza también el nivel subjetivo: hay una "sobreidentificación" entre ambos, un deseo de borramiento de la diferencia y de una suerte de homologación. Laura señala: "Sólo Laurent era mi identidad, pues al no cambiar él yo permanecía en mí que era él mismo" (46). Es decir, se sobrepasa, aunque en términos metafóricos, la complementariedad para llegar incluso a una fagocitación recíproca.

Esta fusión coexiste con otro tipo de agenciamiento, más bien del orden de un movimiento triangular o tripartito, incluso geométrico-astronómico, conformado por las líneas de continuidad entre Laurent, el Sol y Laura. Ella envía escrito en un cartel: "Sol que es Laurent", y recibe del niño el mensaje: "Sol que es Laura Sol Laurent” (23). Más allá de las fallas de composición sintáctica en un niño que está aprendiendo a leer y a escribir (el montaje entre los nombres no ordenados en funciones sintácticas diferenciadas: Laura, Sol y Laurent, y plegados entre sí como si fueran una misma gran cosa); se escenifican las líneas de continuidad, el movimiento irrestricto y asimilador de identidades, en que el Sol funciona como un nuevo afluente de intensidades. Laura anuncia: "el milagro había cuajado, Laurent era yo y yo Laurent, y ambos retornábamos al sol" (23). Precisamente, el deseo amoroso está en plena circulación y excede la célula de amor primaria cifrada en "Laura ama a Laurent" (24). Laurent entonces escribe: "Laurent que ama a Laura Sol" (24). De modo que en aquel triángulo sin jerarquías, en que los afectos circulan

${ }^{31}$ Esta construcción no está exenta, sin embargo, de un plegamiento a formas de amor romántico (y su uso en el melodrama). Tiene pervivencias del mito de los andróginos de El banquete de Platón y constituye una suerte de exageración de aquel ideal de complementariedad amorosa (adquiere incluso tintes paródicos por la materialidad de su designio). 
en todas las direcciones entre Laura, Laurent y el Sol, se advierte que el tercer término es el astro que precisamente le es escatimado a Laurent. El sol ilimitado es una figura ajena a su cotidianeidad, de modo que alberga también la posibilidad de disponer de la propia libertad. Además de aquellas formas de asimilación triangulares, cabe señalar que los nombres Laura y Laurent son también formas de algún tipo de triángulo nominal de Laurus (aceptando la hipótesis de que Laurentium -de donde viene Laurentius - deriva de allí). Esto es, se trata de dos derivaciones diferentes con otros recorridos etimológicos pero con la misma raíz, de la misma manera que ocurre con la deriva genealógica de estos personajes como tía-prima y sobrino-primo: dos individualidades bifurcadas que se (re)encuentran en el mismo espacio.

El nombre suplementario se adquiere en la medida en que cambian los agenciamientos y la economía del deseo (Guattari y Rolnik) se vuelve otra, aunque la anterior esté presente de forma latente. Precisamente cuando Laura es condenada a permanecer en un cierto "exilio" dictado por su tía en la hacienda de Las Nubes, ésta decide hacerle tomar clases de piano con la señorita Hildergaard, cuyo criterio de selección consistió en que fuera soltera y que no hubiera mantenido relaciones con hombres. Esa fórmula de "bloqueo amoroso", de inhibir todo contacto con personas que hubieran experimentado esos vínculos, e incluso de clausurar la ventana de Laura con barrotes para prevenir un nuevo embarazo adolescente, en realidad hace afluir otras líneas de pasaje de intensidades amorosas.

Si el vínculo Laura-Laurent se tiñe de cierto carácter incestuoso -aunque no de primer grado, ya que son tía-prima y su sobrino-primo-, y se presenta como aberración moral; aquí va a estar matizado por cierto afecto lésbico que se figura de forma implícita como una línea de intensidades afectivas entre dos mujeres (una adolescente y una mujer adulta). A pesar de no tratarse de un vínculo sexual, en términos de la imposibilidad de su clasificación también constituye un escándalo de la moral religiosa. "Fräulein Hilde, como yo había empezado a llamarla, me besó por primera vez en mi rostro, mis manos" (49). La primera acción de Hildegaard es tomar a Laura de las manos y, precisamente, otorgarle un suplemento nominal: 
CATEDRAL TomADA: Revista de crítica literaria latinoamericana / Journal of Latin American Literary Criticism

El nombre propio como modulador de vínculos sexo-afectivos y genealógicos en las novelas de Armonía Somers: una poética de la suplementariedad nominal

"Midió mis dedos con los suyos, los flexionó, dejó caer mis muñecas varias veces y dijo simplemente con su acento inconfundible: "no sólo Laura, sí Laura Melodie, Melodie, ja, ja" (46). De esta manera, quien fue llamada para aplacar y "domesticar" a Laura, la hace entrar en otra economía del deseo en la cual una de las piezas fundamentales -incluso mágica- está en el momentáneo corrimiento de su nombre "original” y la sobreimpresión del nombre "Melodie". Allí no sólo se prefigura el potencial nominal para establecer nuevos e inéditos agenciamientos sino que, de la misma manera que en la díada Laura-Laurent, el suplemento está revestido de un fuerte plus de significación. Si "Melodie" es, en términos de las significaciones heredadas del sustantivo común, una melodía, entonces es una intensidad musical que posibilita pasajes y flujos en virtud de lo continuo que parece ser propio de un arte que se desenvuelve en el tiempo (y que ambos personajes comparten). Asimismo, los agenciamientos primarios que se posibilitan, son, del mismo modo que en Laura-Sol-Laurent, triangulares, no binomios sino trípticos plegados sobre sí. Melodie, Fräulein y Mozart (o más bien la música de Mozart) entran en una relación de amor musical cuasi extática: "Mientras pasaban los años, y Fräulein, Mozart y yo seguíamos en el amoroso connubio que a veces otros grandes solían interferir con lo suyo" (Somers 51) (Los subrayados son propios). Nuevamente hay un momentáneo olvido del nombre "primigenio" y la adopción (o más bien, imposición) de otro que permite el pasaje de otras intensidades. Fräulein Hildegaard otorga nombres suplementarios pero no con fines pedagógicos. El tipo de colonización que produce es, al igual que en el caso de Laura y Laurent, de tipo amorosa, pero a ésta se suma una suerte de colonización egocéntrica que busca reproducir (o invocar) algunos los nombres de seres cercanos, de la infancia y otorgárselos a estas nuevas personas con las que se vincula como una forma de acercamiento de éstos a sí misma y a su propia biografía. Pero también busca generar una especie de nido de infancia que evoque aquellos afectos primigenios. ${ }^{32}$ De hecho, al final, en el fragmento narrado por

${ }^{32}$ Uno de los suplementos otorgados por Hildegaard: "Zauberei" (magia en alemán), desplaza el nombre del caballo que le asignan en Las Nubes ("Tormenta"). Zauberei era el caballo de la 
Fräulein Hildegaard, se revela que el nombre "Melodie" es, en principio, el suyo propio, se lo cambia a Hildegaard al momento de morir su madre. ${ }^{33}$ De modo que en el acto de nombrar a Laura "Melodie" (y luego se revela su existencia como "Melodie II") hay un gesto de vuelta a sí misma, a la infancia en Laura a la vez que una identificación con ella: se trata de una invitación implícita a Laura a consustanciarse con aquellas épocas primigenias de su vida. En algún sentido, es un mecanismo similar al deseo de fusión corporal entre Laura y Laurent, sólo que en este caso se trata de una fusión nominal (y, por supuesto, subjetiva).

Por otra parte, es importante señalar el doble origen religioso de la protagonista. Bien avanzada la novela, ella declara: "Yo soy Laura Kadisja Hassan y Cienfuegos; Laura, quizás lo soñado por mi madre; Kadisja, primera mujer del profeta, por el nombre de mi abuela paterna que lo llevaría con mucha honra, siendo mi madre y mi abuelo, ambos, Mohamed Hassan" (Somers 83). De modo que es mitad árabe y mitad española cristiana. Si bien las suplementariedades nominales no están directamente relacionadas con la genealogía de Laura, como ocurría con Sembrando Flores en SLEEM, su herencia híbrida no deja de ser un factor que favorece la horadación de las estructuras de poder familiar. Su posición bilateral propicia una forma de intervención dentro de su familia de raigambre española (sus padres murieron en un naufragio), bajo el ala de Encarnación, desde el cuestionamiento y la irreverencia. De hecho, es el único personaje de quien se señala la necesidad de ser "domesticado".

Asimismo, es interesante que los nombres de Macario ("el dichoso") y de Eulalia ("dulce habla") provengan del griego. Es también en griego que Fräulein Hildegaard redacta su último mensaje para Laura: "Bésame y dame la mano"

infancia de Hildegaard, al que matan unos mineros por sonreír "como humano". En virtud de los significados traficados del sustantivo común al nombre, se advierte el desplazamiento de la idea de "tormenta" como fenómeno atmosférico desapacible y natural a la "magia" en alemán, como un dominio que presupone lo sobrenatural y lo prodigioso. Nuevamente se trata de nombres en que pervive con mayor énfasis el significado del sustantivo común del que derivan.

33 "Los oigo pronunciar mi nombre, mi verdadero nombre. Que nunca digo. Que no revelo a nadie. Ni siquiera al padre de Pierre. Porque Hildegaard es el de mi madre. Y yo lo adopto luego de su triste muerte contra mí" (139). 
CATEDRAL TOMADA: Revista de crítica literaria latinoamericana / Journal of Latin American Literary Criticism

El nombre propio como modulador de vínculos sexo-afectivos y genealógicos en las novelas de Armonía Somers: una poética de la suplementariedad nominal

(141). ${ }^{34}$ Tanto Macario como Eulalia se presentan junto con sus significados etimológicos, que están signados por disposiciones placenteras y armónicas: la dicha y la dulzura del habla. En cierto sentido, son personajes "resguardados" de la(s) verdad(es) familiares, los secretos, las manipulaciones genealógicosubjetivas; pero en entornos que se pretenden de cuidado, en utopías falsas. De algún modo, con aquella "ignorancia" se pretende que estos personajes devengan en una existencia plácida y desmarcada.

Por último, resta explicar por qué no hicimos un rastreo de los desplazamientos de las convenciones ad hoc en el caso de $V A C D D$. Descubrimos que las mutaciones subjetivas, de modo similar que en $L M D$ pero con algunas diferencias, no están tanto en la modificación de los referentes individualmente sino en los procesos intersubjetivos, amorosos y eróticos de los que participan. Esto es, los cambios no se verifican en sí en las descripciones mostrativas que aparecen y se modifican en torno de los personajes, sino más bien en la creación de conglomerados de grupo, bipartitos o tripartitos que funcionan como agenciamientos exploratorios de las posibilidades inéditas del deseo y de su habilitación inaugural.

\footnotetext{
${ }^{34}$ Estos nombres además contrastan con los nombres de la autoridad y su ayudante: Encarnación y Refugio. Esto es, nombres dotados de una raigambre cristiana: "los nombres que llevamos, al menos tu y yo, Refugio, no caen al azar o son elegidos por capricho, vienen a nosotros por un designio superior que traemos y el nombre y alguien de este mundo nos lo adjudica en el bautismo" (32). Encarnación y Refugio tienen reminiscencias en relación con el deber religioso: "encarnar" (el Verbo de Dios como Jesucristo, por el poder del Espíritu Santo); y moral: "refugiar" y dar asilo. Tomando esta teoría del nombre de Encarnación -que éste tiene un "designio superior"-, se puede pensar qué tipo de intención divina se puede asociar a los nombres de su hija y de su nieto. El nombre con que fue bautizado originalmente Laurent es "Macario", y el padre Artemio, de quien Laura obtiene la información, "añadió: del griego, Dichoso, domingo 15 de enero" (Somers 16) (los subrayados son propios). La madrina es Refugio Robles, además sus apellidos son "Belleau Cienfuegos". Como señala Laurent, se supone que él es "hijo" sus abuelos y, para peor, "uno de ellos archimuerto", "entonces eso quiere decir que no nací y si no nací quién será el que muera cuando eso suceda" (Somers 84) (El subrayado es propio). De modo que los apellidos de Laurent-Macario (Belleau Cienfuegos), al indicar una genealogía desviada, también son marca nominal de la imposibilidad (entrañan dicho efecto subjetivo de la condición de nonacido) curiosamente, a partir de la manipulación nominal.
} 


\section{Contrastes entre LMD, SLEEM y VACDD}

Para concluir este artículo, podemos señalar las diferencias entre $V A C D D$, $L M D$ y SLEEM. En $L M D$ la suplementariedad nominal es practicada por la protagonista principalmente como forma de auto-nominación e invocación mística (Eva-Semíramis-Magdala-Judith-Gradiva-Friné). Los signos cargan algo de la energía simbólica y vital de su referente "primario" y se reinyectan en el nuevo referente, aunque las mutaciones subjetivas e intersubjetivas excedan a esas figuras. De modo que la protagonista tiene un fuerte factor de agencia y de autoinvención: los nuevos nombres señalizan como faros aquel devenir primigenio, erótico, nómade y hombruno, y sus agenciamientos amorosos. En estas re-subjetivaciones emerge una especie de pulsión hacia la de-subjetivación, hacia un horizonte de neutralidad o un efecto de disolución en todas ellas, y no plenamente la búsqueda de un índice de diferencia.

En el espectro contrario está Sembrando Flores en SLEEM, quien otorga algunos nombres nuevos (a Tiberíade, al gato Cantaclaro), pero su gesto primordial es de cierta pasividad nominal. Los nombres de múltiples orígenes que se le endilgan son resultado de herencias y del trazado de distintas (y delirantes) líneas genealógicas: familiares, ideológicas, literarias y médicas. Estas transacciones de suplementos nominales hacen estallar la certidumbre de un origen único, y como habíamos dicho, muchas de ellas se realizan de forma retrospectiva. La adquisición de suplementos como "El Quilotórax" y "El caso" generan un efecto de desubjetivación pero de cuño negativo, de vaciamiento de la identidad de Sembrando Flores, mientras que la desubjetivación de $L M D$ era una potencia de desujeción de los imperativos morales.

Por último, en el caso de $V A C D D$ la operación de suplementariedad nominal que está en primer plano es la nominación del otro (ya no de sí mismo como en $L M D$ ), y adopta la forma de una colonización (pedagógica o cuasiegocéntrica). Ésta abre posibilidades sexo-afectivas cuya potencia reside en su secreto, por lo cual, se trata de líneas de fuga amorosas y de deseo que pueden realizarse al margen o en ausencia del personaje que dicta la norma (Encarnación). 
CATEDRAL TomadA: Revista de crítica literaria latinoamericana / Journal of Latin American Literary Criticism

El nombre propio como modulador de vínculos sexo-afectivos y genealógicos en las novelas de Armonía Somers: una poética de la suplementariedad nominal

En cierto sentido, se produce una lógica colonizadora que quiebra, al menos por momentos, la discontinuidad de las subjetividades y los cuerpos e implica una práctica de sumisión y entrega, en que el personaje es lo que el dador de nombres quiere que sea.

\section{Bibliografía}

Agamben, Giorgio. Desnudez. Adriana Hidalgo, 2011.

Barthes, Roland. "Proust y los nombres". El grado cero de la escritura seguido de Nuevos ensayos críticos. Siglo Veintiuno, 2006.

Bataille, Georges. El erotismo. Tusquets, 1997.

Butler, Judith. El género en disputa: el feminismo y la subversión de la identidad. Paidós, 2007.

Calafell Sala, Núria. Armonía Somers: por una ética de lo excéntrico. Academia del Hispanismo, 2010.

. "Todas en ella: Armonía Somers y la lectoescritura como construcción identitaria". Nomadías, no. 13, julio, 2011, pp. 31-45.

Dalmagro, María C. "Mujeres en el campo intelectual uruguayo: Armonía Somers: entre la transgresión y el seudónimo". Universum, no. 17, 2002. . Desde los umbrales de la memoria: ficción autobiográfica en Armonía Somers. Biblioteca Nacional de Uruguay, 2009.

. "La autoficción como espacio de re-construcción de la memoria." Recial. vol. 8, no. 11, 2017.

Deleuze, Gilles y Guattari, Félix. Mil mesetas: capitalismo y esquizofrenia. Pretextos, 2002.

Derrida, Jacques. De la gramatología. Siglo veintiuno, 1986.

Foucault, Michel. Historia de la sexualidad: 1. la voluntad del saber. Siglo veintiuno, 2012.

Frege, Gottlob. "Sobre sentido y referencia". Ensayos de semántica y filosofía de la lógica. Tecnos, 1998.

Freud, Sigmund. El delirio y los sueños en la Gradiva de W. Jensen, Obras Completas de Sigmund Freud. (XII), 1907.

Giglio, María Esther. "A cada cual su ración de amor. Responde Armonía Somers". Marcha, año 27, no. 1298, 1966.

Guattari, Félix y Rolnik, Suely. Micropolítica: cartografias del deseo. Traficantes de sueños, 2006. 
Hall, Stuart. “¿Quién necesita "identidad”?”. En S. Hall y P. du Gay (Eds.), Cuestiones de identidad cultural. Amorrortu, 2003.

Kripke, Saul. El nombrar y la necesidad. Universidad Nacional Autónoma de México, 1995.

Kristeva, Julia. "El sujeto en cuestión: el lenguaje poético", en Levi- Strauss, c. (Ed.) Seminario: la identidad. Petrel, 1981.

Lacan, Jacques. "Seminario 10 bis: Los nombres del padre". 1963. Recuperado de: http://www.bibliopsi.org/docs/lacan/13\%20Seminario\%2010bis.pdf

Paracelso. Botánica oculta: tratado de las plantas mágicas. Edicomunicación, 1999.

Platón. Diálogos, vol. III. Gredos, 2000.

Ricoeur, Paul. Sí mismo como otro. Siglo veintiuno, 2006.

Rodríguez Villamil, Ana María. Elementos fantásticos en la narrativa de Armonía Somers. Ediciones de La Banda Oriental, 1990.

. "Utopía y distopía en la literatura uruguaya". Encuentros y desencuentros. $(\mathrm{S} / \mathrm{F})(\mathrm{S} / \mathrm{L})$.

Russell, Bertrand. "Knowledge by acquaintance and knowledge by description". Proceedings of the Aristotelian Society, vol. 11, pp. 200-221, 1911.

Searle, John .R. Nombres propios y descripciones En L. Manuel Valdés Villanueva (Ed.) La búsqueda del significado. Tecnos, 1999.

Somers, Armonía. La mujer desnuda. El cuenco de plata, 1950 (2009). . Sólo los elefantes encuentran mandrágora. El cuenco de plata, 1986 (2010). . Viaje al corazón del día: elegía por un secreto amor. El cuenco de plata, 1986 (2011).

Strawson, Peter. "Sobre el referir". En L. Manuel Valdés Villanueva (Ed.) La búsqueda del significado. Tecnos, 2005.

Zanetti, Susana. "La dorada garra de la lectura. Sólo los elefantes encuentran mandrágora de Armonía Somers". La dorada garra de la lectura. Lecturas y lectores de novela en América Latina. Beatriz Viterbo, 1996. 